\title{
Memahami Multikulturalisme Orang Betawi: Modal kultural untuk Efektivitas Komunikasi Antarbudaya Masa Kini
}

\author{
Halimatusa'diah ${ }^{1^{*}}$ \\ ${ }^{1}$ Peneliti Pusat Penelitian Masyarakat dan Budaya, LIPI \\ * Email Korespondensi: Halimatusadiah8015@gmail.com
}

\begin{abstract}
A B S T R A K
Kata kunci:

Betawi

Budaya

Komunikasi

Multikulturalisme

Dinamika komunikasi kontemporer, tak pernah bisa lepas dari persoalan interaksi antarbudaya dalam masyarakat kita yang majemuk. Keberagaman suku bangsa atau etnis di Indonesia di satu sisi memang menjadi anugrah kekayaan kultural yang jarang dimiliki oleh bangsa-bangsa lain. Makalah ini berpijak pada apa yang dikemukakan oleh Edward T. Hall yang mengemukakan bahwa budaya adalah komunikasi dan komunikasi adalah budaya. Studi ini menggunakan pendekatan kualitatif dengan wawancara mendalam kepada beberapa narasumber baik dari Orang Betawi maupun orang di luar Betawi. Selain wawancara, studi literatur juga dilakukan guna mendukung argumen dalam penelitian ini. Sikap terbuka dan egaliter orang Betawi juga terobservasi melalui gaya komunikasi mereka. Secara umum, pola komunikasi Orang Betawi berada dalam komunikasi konteks rendah dan juga konteks tinggi.

\section{A B S T R A C T}

Keyword:

Betawi

The dynamics of contemporary communication can never be separated from the problem Culture

Communication

Multikulturalism of intercultural interaction in our pluralistic society. The diversity of ethnic groups in Indonesia, on the one hand, is indeed a gift of cultural wealth that is rarely owned by other nations. This paper is based on what was stated by Edward T. Hall, who stated that culture is communication and communication is culture. This study uses a qualitative approach with in-depth interviews with several sources, both from Betawi people and people outside Betawi. Apart from interviews, literature studies were also conducted to support the arguments in this study. The Betawi people's open and egalitarian attitudes are also observed through their communication style. In general, the Betawi people communication patterns are in low context and high context communication.
\end{abstract}

\section{PENDAHULUAN}

Berbicara tentang dinamika komunikasi kontemporer, tak pernah bisa lepas dari persoalan interaksi antarbudaya dalam masyarakat kita yang majemuk. Dalam kehidupan kita sehari-hari, perilaku komunikasi kita, tidak terlepas dari akar budaya kita (Samovar, 2013; Ting Toomey, 2005). Komunikasi antarbudaya yang efektif, hanya dapat terjadi apabila ada kesadaran tentang perbedaan budaya antara komunikator dan komunikan (Ting Toomey, 2005). Oleh karena itu, mengenali perbedaan budaya, akan membantu meningkatkan kesadaran perbedaan dalam interaksi antarbudaya, mengurangi stereotype dan prasangka yang dapat berujung pada konflik seperti yang terjadi di beberapa daerah saat ini.
Keberagaman suku bangsa atau etnis di Indonesia di satu sisi memang menjadi anugrah kekayaan kultural yang jarang dimiliki oleh bangsa-bangsa lain. Namun, keberagaman ini dapat menjadi bumerang bilamana di dalam masyarakat masih terdapat individu yang mengagungkan sikap etnosentrisme yaitu suatu kecenderungan yang menganggap nilai-nilai dan norma kebudayaannya sendiri sebagai sesuatu yang terbaik. Padahal, di dalam kehidupan ini kita akan senantiasa dihadapkan dengan orang-orang yang berbeda budaya, yang memiliki nilai-nilai budaya yang juga berbeda. Sayangnya, keberbedaan masih dipahami dalam konteks "kita" dan "mereka" sebagai "yang berbeda" bukan "kita bersama mereka yang bersatu di bawah naungan yang sama" yakni Indonesia.

Makalah ini berpijak pada apa yang dikemukakan oleh Edward T. Hall yang mengemukakan bahwa budaya adalah 
komunikasi dan komunikasi adalah budaya (Samovar, 2013). Oleh karena itu, kearifan budaya dalam masyarakat tertentu penting untuk digali guna meningkatkan wawasan dan pemahaman masyarakat untuk menciptakan komunikasi antarbudaya yang efektif. Dari makalah ini, kita dapat memahami bahwa kearifan budaya dapat menjadi modal yang kuat untuk menciptakan kohesi sosial dan meredam konflik dalam masyarakat kita yang majemuk. Studi ini sangat penting untuk dikaji di tengah keragaman etnis, agama, maupun bahasa yang dimiliki oleh Bangsa Indonesia. Interaksi antarbudaya tidak dapat dihindari atau diabaikan, karenanya kita akan seringkali berkomunikasi dengan orang lain yang berbeda latar belakang budaya. Kita juga akan dihadapkan dengan perbedaan nilai-nilai, bahasa dan aturan-aturan yang berbeda. Akan sulit bagi kita untuk memahami komunikasi antarbudaya apabila kita tidak mengenal keragaman budaya yang ada. Komunikasi antarbudaya yang berlangsung efektif, dapat melahirkan sikap menerima, toleransi dan menghargai budaya lain yang pada gilirannya mampu membangun hubungan harmonis di antara orang-orang yang berbeda latar belakang budaya.

\section{METODE PENELITIAN}

Studi ini menggunakan pendekatan kualitatif dengan wawancara mendalam kepada beberapa narasumber baik dari Orang Betawi maupun orang di luar Betawi. Pandangan orang di luar Betawi sangat penting untuk validitas data dengan melihat bagaimana pandangan orang luar tentang multikulturalisme Orang Betawi. Selain wawancara, studi literatur juga dilakukan guna mendukung argumen dalam penelitian ini. Selain itu, kajian literature juga dilakukan untuk melihat celah penelitian dari studi-studi yang telah dilakukan sebelumnya, sehingga kebaruan dari penelitian ini dapat dipertanggungjawabkan.

\section{HASIL DAN PEMBAHASAN}

\author{
Budaya, Komunikasi, dan Interaksi \\ Antarbudaya
}

Budaya, sama seperti komunikasi, sukar untuk menemukan makna maupun definisi tunggal. Hal ini disebabkan oleh perbedaan prespektif ataupun paradigma dalam memahami permasalahan dunia, khususnya budaya (Samovar, Porter, \& McDaniel, 2010: 23). Oleh karena itu, tidak mengherankan jika kemudian Ting Toomey (1999:9), menyebut budaya sebagai enigma, yakni sebuah teka-teki atau pernyataan yang membingungkan. Budaya (culture), didefinisikan oleh Martin dan Nakayama (2011: 81) "sebagai pola-pola yang dipelajari dari perilaku dan sikap yang disebarkan oleh sebuah kelompok masyarakat."

Setiap kebudayaan mengajarkan caracara tertentu untuk memproses informasi yang masuk dan keluar dari atau ke lingkungan sekeliling mereka, misalnya mengatur bagaimana setiap anggota budaya memahami cara mengemas informasi kemudian melakukan pertukaran informasi. Dalam kaitan ini, Edward T. Hall menyatakan bahwa kebudayaan adalah komunikasi dan komunikasi adalah kebudayaan. Apabila berbicara mengenai pola budaya, maka tidak akan bisa lepas dari pola komunikasi, sama halnya komunikasi dan budaya yang saling berhubungan. Pola budaya mempengaruhi pola komunikasi seseorang dalam berkomunikasi dan pola komunikasi mempengaruhi pola budaya seseorang. Hal tersebut dikarenakan pola budaya dan pola komunikasi saling berhubungan dan saling berkaitan satu sama lain. Pola budaya setiap kelompok masyarakat berbeda-beda dalam menjalankan aturan, cara berinteraksi, bahasa, nilai dan norma. Perbedaan pola budaya seseorang akan terlihat sangat mencolok saat terjadi komunikasi antarbudaya, karena orangorang yang terlibat dalam komunikasi antarbudaya tersebut secara tidak langsung akan menunjukkan pola budaya yang dimilikinya saat komunikasi antarbudaya berlangsung. Hal ini yang disebut sebagai pola komunikasi antarbudaya, yaitu pola komunikasi yang terjadi antara orang-orang yang memiliki budaya yang berbeda.

Secara mendasar berarti ada hubungan antara budaya dengan komunikasi. Budaya mempengaruhi komunikasi dan komunikasi mempengaruhi budaya. Komunikasi kultural memberikan seperangkat hal-hal yang ideal tentang bagaimana interaksi sosial dapat dijalankan dengan lancar di antara individu- 
individu dalam suatu komunitas. Budaya mengikat orang bersama-sama melalui kodekode linguistik yang dipertukarkan, normanorma, dan scripts, yaitu rangkaian interaksi atau pola-pola komunikasi yang dipetukarkan oleh sekelompok orang dalam suatu komunikasi ujaran. Hubungan antara budaya dan komunikasi merupakan suatu permasalahan yang kompleks. Budaya dan komunikasi sangat terkait erat dan bersifat timbal balik, seperti yang dikatakan oleh Martin dan Nakayama (2007: 92), "budaya mempengaruhi komunikasi, dan sebaliknya".

\section{Etnis Betawi}

Dalam kaitannya dengan etnis Betawi, terdapat beberapa kajian akademis yang menelaah proses pembentukan etnis ini. Castles (1967) misalnya, mengatakan bahwa Betawi muncul karena adanya asimilasi budaya ${ }^{1}$. Sementara Chaer (2015:10-11) seorang tokoh budayawan Betawi menuliskan pandangannya

${ }^{1}$ Asimilasi merupakan suatu evolusi dari sebuah proses pengambil alihan unsur-unsur (sifat) kebudayaan lain yang berbeda oleh sebuah kelompok atau individu. Proses ini disebut sebagai sebagai akulturasi, yakni suatu proses sosial yang timbul ketika suatu kelompok manusia dengan kebudayaan tertentu dihadapkan dengan unsur dari suatu kebudayaan asing. Lambat laun kebudayaan asing tersebut diterima dan diolah dalam kebudayaannya sendiri tanpa menyebabkan hilangnya unsur kebudayaan kelompok itu sendiri. Adalah suatu hal yang menarik ketika melihat dan mengamati proses akulturasi tersebut sehingga nantinya secara evolusi menjadi Asimilasi yaitu meleburnya dua kebudayaan atau lebih, sehingga menjadi satu kebudayaan. Dalam asimilasi unsurunsur budaya pembentuknya hanya sedikit terlihat karena telah membentuk suatu budaya baru. Akulturasi budaya dapat terjadi karena keterbukaan suatu komunitas masyarakat akan mengakibatkan kebudayaan yang mereka miliki akan terpengaruh dengan kebudayaan komunitas masyarakat lain. Selain keterbukaan masyarakatnya, perubahan kebudayaan yang disebabkan "perkawinan" dua kebudayaan bisa juga terjadi akibat adanya pemaksaan dari masyarakat asing memasukkan unsur kebudayaan mereka. Akulturasi budaya bisa juga terjadi karena kontak dengan budaya lain, system pendidikan yang maju yang mengajarkan seseorang untuk lebih berfikir ilmiah dan objektif, keinginan untuk maju, sikap mudah menerima halhal baru dan toleransi terhadap perubahan. sendiri dalam melihat siapa yang dimaksud dengan etnis Betawi. Chaer menggunakan beberapa kriteria atau pendekatan untuk menentukan etnis Betawi atau bukan, yaitu pendekatan sejerah, pendekatan lokasi (tempat), pendekatan kesamaan bahasa, pendekatan agama (Islam), dan pendekatan campuran antara pendekatan lokasi dan agama. Pendekatan sejarah menyatakan bahwa orang Betawi atau etnis Betawi adalah etnis yang lahir dari pencampuran pernikahan berbagai etnis yang ada di Batavia pada abad ke-17 dan ke-18. Pendekatan lokasi adalah nama tempat atau lokasi yang identik dengan Batavia pada masa VOC dan Hindia Belanda atau Jakarta sebelum proklamasi Kemerdekaan. Jika pendekatan lokasi yang digunakan untuk menyatakan siapa orang Betawi, maka jelas orang Betawi adalah Pribumi yang ada di kota Batavia, yang oleh Residen Batavia disebut Bataviaan (Lohanda, 2004). Jadi, siapapun yang berada di luar Batavia bukan orang Batawi. Pendekatan bahasa menyatakan orang Betawi adalah orang yang menggunakan bahasa Melayu Betawi ${ }^{2}$. Pendekatan agama melihat etnis Betawi dari agama Islam. Jika pendekatan agama yang digunakan, maka komunitas di Kampung Sawah di Kampung Tugu bukanlah orang

2 Lalu menurut hasil penelitian Muhadjir, dkk (1986), penggunaan bahasa Betawi bukan hanya di wilayah administrasi pemerintahan DKI Jakarta saja, tetapi jauh sampai ke wilayah Tangerang di sebelah barat; jauh sampai ke wilayah Depok/Bogor di sebelah selatan; dan jauh sampai ke wilayah Bekasi disebelah timur (Multamia, 1986). Jika pendekatan penggunaan bahasa juga dipakai, maka orang Betawi mempunyai wilayah kedudukan yang sangat luas, termasuk komunitas Kampung Sawah di Pondok Gede yang beragama Kristen (Firmansyah, 2012), dan Komunitas Masyarakat Tugu yang beagama Kristen (Abdurrahman,1975). Menurut keterangan lisan Uri Tadmor, seorang Jerman peneliti bahasa Melayu bahwa sebenarnya Komunitas Tugu juga berbahasa Melayu dengan kosakata yang banyak diambil dari bahasa Portugis (Tadmor, 2007). Grijns (1991a) juga melihat Betawi-ia menyebutnya Jakarta-dari penggunaan bahasa sehingga wilayah penelitian mulai dari Tangerang di sebelah barat, Cisalak disebelah selatan dan Bekasi di sebelah timur. 
Betawi. Berikutnya adalah yang menggabungkan pendekatan agama (Islam) dan lokasi (tempat). Jadi, seorang Betawi adalah yang tinggal di kota Batavia (Jakarta sekarang) dan beragama Islam. Kiranya pendekatan inilah yang banyak dianut dan dipahami orang Betawi pada waktu yang lalu. Oleh karena itu, mereka menyebut dirinya orang Betawi atau orang Selam (Islam).

\section{Islam dan Kolektivisme: Orientasi Budaya Orang Betawi}

Orang Betawi dikenal sebagai pemeluk agama Islam yang sangat baik dan taat dalam menjalankan ajaran agamanya (Chaer, 2015; Blackburn, 2010; Saidi, 1997, 2015). Oleh karena itu, setiap aktivitas yang dilakukan di antara masyarakat Betawi tidak lepas dari agama Islam, meskipun ditemukan juga etnik Betawi yang menganut agama Kristen Protestan dan Katolik yang sedikit sekali jumlahnya. Prinsip hidupnya adalah ngasosi, yaitu ngaji, solat, dan silat (ilmu beladiri). Pemahaman tentang ilmu agama merupakan kompetensi utama bagi orang Betawi. Bahkan, sosok orang alim mendapat kedudukan yang tinggi dalam struktur sosial masyarakat. Peranan mereka dalam masyarakat seringkali mengalahkan pemimpin formal, karena apa yang mereka sampaikan selalu dipatuhi oleh masyarakat Betawi. Tokoh-tokoh agama mempunyai pengaruh yang besar sekali pada kehidupan orang Betawi.

Bagi kaum Betawi, persoalan kesukuan dan etnis bukanlah sesuatu yang utama dan pertama, karena di tengah masyarakat yang plural dan multikultural, hal yang utama adalah dimensi kebangsaan (Haesy, 2017: 304). Dalam diri Orang Betawi mengalir esensi nilai kepribadian yang bersumber dari ajaran agama Islam. Kaum Betawi dicirikan oleh sikap egaliter, sikap terbuka, agama Islam, dan bahasanya. Itulah sebabnya mengapa kaum Betawi tidak memandang penting gelar dan pemeringkatan struktural kehidupan sosialnya. Nilai ini yang memungkinkan kaum Betawi lebih fleksibel dan akomodatif terhadap perubahan sosial.

Orang Betawi menganut nilai budaya kolektivisme. Hal mi terlihat dan ciri-ciri masyarakat Betawi yang memegang teguh prinsip kerukunan, keakraban, mendahulukan kepentingan umum daripada kepentingan pribadi, serta melakukan pengorbananpengorbanan untuk membantu kerabatnya. Masyarakat Betawi juga memandang kehidupan semesta merupakan satu kesatuan yang utuh. Ada ikatan yang kuat antara manusia dengan Sang pencipta-Nya dan makhluk lainnya, tumbuhan, hewan (makhluk ghaib dan non ghaib) hal ini bisa kita lihat dalam filosofi gigi balang (hiasan pada lisplang rumah adat Betawi). Gigi balang itu casing, seperti juga bentuk wajik, daun dan lainnya. Tapi intinya, semua berpusat pada kedalaman makna segitiga, hubungan harmonis antara Allah (puncak), manusia dan makhluk lainnya.

Jadi bicara orang Betawi adalah orang yang percaya pada kekuatan yang Maha Tinggi dan mencintai alam berserta isinya. Gigi balang menurut Yahya Adi Saputra adalah bentuk gunung yang sudah lama dipercaya sebagai symbol kepercayaan pada kekuatan yang Maha Tinggi. Begitulah cinta sejati orang Betawi, cinta universal yang dekat dengan pecipta-Nya dan semesta beserta isinya. Nilai filosofi yang dalam tentang bentuk segitiga gigi balang dan daun, dimaknai sebagai bentuk hadirnya Sang Maha Pencipta di mana saja. Daun dan bentuk segitiga ada dimana-mana. Jadi, ingat daun ingat adanya Allah SWT dan juga adanya makhluk lainnya. Ada cinta sejati orang Betawi pada setiap sudut semesta. Ini adalah bentuk cinta mendalam yang akan membimbing manusia terbebas dari bahle (bencana) baik di dunia dan di akhirat (Rahmad Sadeli, 2018).

Dari filosofi gigi balang tersebut; masyarakat Betawi diharapkan untuk bisa mengatur hidup masing-masing yang selaras dengan masyarakat serta alam semesta. Hal ini sejalan dengan nilai-nilai keislaman yang dianut Orang Betawi "Habluminaallah, Habluminnas, Habluminnal'alam" (Roni Adi, 2018). Dalam membina kekerabatan, masyarakat Betawi memegang teguh prinsip kerukunan yaitu prinsip yang menuntut individu untuk mementingkan kepentingan umum diatas kepentingan pribadi. Selain itu mereka juga sangat menjaga hubungan sosialnya. Solidaritas antar anggota masyarakat mempunyai peranan yang penting serta mempunyai nilai emosional yang tinggi.

\section{Sikap Terbuka dan Egaliter: Nilai Dasar Multikulturalisme Orang Betawi}


Multikulturalisme adalah tentang bagaimana kelompok-kelompok sosial atau komunitas-komunitas kultural yang berbeda bisa hidup berdampingan dalam sebuah wilayah tertentu. Multikulturalisme menekankan pada kesetaraan antar kelompok budaya yang ada dalam sebuah masyarakat (Suparlan, 2005:98). Multikulturalisme, seperti dikemukakan Azra (2006:154), adalah semangat untuk hidup berdampingan secara damai dalam perbedaan budaya baik secara individual maupun secara kelompok. Dalam kaitannya dengan hal tersebut, Orang Betawi, sebagai kelompok etnik yang lekat dengan identitas Islam, menjadikan norma agama sebagai landasan berkehidupan dalam masyarakat. Selain dikenal sebagai kelompok etnik yang kosmopolit (Haesy, 2017) Betawi juga dikenal dengan kelompok etnik yang mengedepankan prinsip egaliter dalam kehidupan bermasyarakat. Prinsip ini lahir dari ajaran agama yang menekankan bahwa semua makhluk adalah "sama" dihadapan Allah SWT. Hal ini tercermin dari beberapa pernyataan informan berikut:

"yang saya suka dari Orang Betawi di sini $t u$, mereka 'open', ya menerima. Menerima orang tua saya, menerima saya. Karena prinsip hidup kita kan sama, kebersamaan dan kesetaraan. Orang Betawi kan menganut prinsip bahwa semua orang sama dihadapan Allah, yang membuatnya berbeda hanya amal kebaikannya. Itu yang saya rasa kenapa mereka bisa bersikap terbuka dan engga primordial." (Wawancara dengan YM, etnis Sunda yang tinggal di lingkungan Betawi Condet, Jakarta, 2018)

"Orang Betawi juga kan enaknya mereka engga ngebeda-bedain siapa kita, mereka terbuka aja. Sebagai contoh misalnya ya ketika saya masuk ke organisasi Rumpun Betawi itu, ga ada tuh mereka yang rasis, darimanapun asal kita ya dirangkul. Itu enaknya di Betawi. Betawi itu menerima segala kalangan, terbuka dan egaliter, jadi kita yang bukan Orang Betawi engga ngerasa dibeda-bedain." (Wawancara dengan SH, etnis Jawa yang tinggal di lingkungan Betawi Kemayoran, Jakarta 2018)

Beberapa pernyataan di atas menunjukkan bagaimana penggambaran Betawi oleh mereka yang bukan Orang Betawi. Dalam pandangan mereka, nilai keterbukaan dan sikap egaliter Orang Betawi merupakan poin penting yang menjadi alasan mereka nyaman untuk berada di tengah-tengah lingkungan Orang Betawi.

Penggambaran tentang Orang Betawi oleh masyarakat non-Betawi di atas, mempertegas apa yang disampaikan oleh Pradipta (2005:32), bahwa Orang Betawi memiliki keunggulan budaya yang terletak pada sifat-sifat istimewa yang secara turun temurun melekat pada diri Orang Betawi itu sendiri. Sikap egaliter ditunjukkan oleh Pradipta (2005:34) melalui penggambarannya tentang Orang Betawi yang memiliki sifat demokrastis, duduk sama rendah, berdiri sama tinggi. Sikap terbuka merupakan pola pikir Orang Betawi yang juga menjadi keistimewaan bagi Orang Betawi. Menurut Pradipta (2005: 32-35) sikap terbuka dan egaliter Orang Betawi tersebut, merupakan nilai yang tertanam dari sifat religiusitas Orang Betawi. Nilai religiusitas inilah yang menjadikan Orang Betawi toleran terhadap siapa saja, baik pribadi, keluarga, komunitas, maupun masyarakat untuk tinggal dan menetap secara merdeka di Jakarta. Nilai-nilai agama Islam juga menjadi pedoman bagi Orang Betawi dalam berinteraksi, baik dengan in-group maupun out-group. Hal ini tampak pada pernyataan informan berikut:

"Betawi kan identik dengan Islam, ya saya selalu mengedepankan adab kita bertemu dengan orang lain. Apapun latar belakang sukunya. Intinya kita menunjukan adab aja ke orang-orang." (Wawancara dengan AC, Tokoh Betawi, Jakarta, 2018)

Penegasan informan di atas juga menunjukkan bagaimana agama, budaya dan prilaku terikat secara implisit. Karena inti agama adalah menyediakan petunjuk mengenai bagaimana untuk memberlakukan orang lain. Prinsip lainnya yang juga menjadi pandangan informan dalam berprilaku sehari-hari adalah 
bahwa hidup harus bisa bermanfaat untuk orang lain.

Saling menghormati, menghargai dan memperlakukan sesama manusia sesuai harkat dan martabatnya merupakan dasar dari sikap etis yang dibawa Orang Betawi dalam setiap interaksi. Menjaga martabat orang lain berarti menyadari adanya perbedaan antara mereka dengan orang lain baik sebagai individu maupun sebagai anggota kelompok. Menghormati orang lain berarti kita memperlakukan orang lain setara, tidak memandang dia sebagai pihak yang lemah atau berada di bawah kita. Infoman mengakui bahwa prilaku saling menghormati, menghargai perbedaan dan kesetaraan merupakan nilai-nilai agama Islam yang sangat dijunjung oleh Orang Betawi. Religius dan terbuka merupakan nilainilai Betawi yang sangat mempengaruhi Orang Betawi dalam berinteraksi.

Orang Betawi mengedepankan nilai persamaan dalam interaksi awal dengan orang asing. Adanya persamaan-persamaan dengan orang asing akan menjadikan kita merasa terhubung dan menjadi satu kelompok dengan orang asing. Peningkatan kesamaan personal yang dirasakan akan menghasilkan penurunan kecemasan dan peningkatan kemampuan kita untuk secara akurat memprediksi perilaku mereka.

Sikap terbuka dan egaliter orang Betawi juga terobservasi melalui gaya komunikasi mereka. Secara umum, pola komunikasi Orang Betawi berada dalam komunikasi konteks rendah dan juga konteks tinggi. Dalam suasana dialog yang tenang, santai penuh canda, Orang Betawi berada pada komunikasi konteks rendah, namun seketika dapat berubah pada konteks tinggi dalam situasi dialog yang berpotensi munculnya ketegangan dan menimbulkan perdebatan. Gaya komunikasi orang Betawi termasuk gaya komunikasi konteks konteks-tinggi, seperti orang Timur umumnya (dan orang Indonesia khususnya) yang tidak terus terang, suka basa-basi dan berbelit-belit dan berbeda dengan pembicara konteks-rendah seperti orang Amerika dan orang Jerman yang berbicara langsung dan lugas. Dengan kata lain, orang Betawi masih berbicara apa adanya, masih kurang jelas dan kurang langsung. Orang Betawi lebih percaya pada komunikasi nonverbal yang dinyatakan melalui status (usia, jenis kelamin, pendidikan, latar belakang keluarga, gelar dan afiliasi) serta melalui teman dan rekan. karena "pesan" digunakan oleh budaya konteks tinggi, anggota kelompok ini, menurut Gudykunst, kadang "komunikasi dalam cara yang tidak langsung. mereka bergantung pada bagaimana suatu itu dikatakan, lebih daripada apa yang dikatakan, dan waspada terhadap isyarat non-verbal.

Gaya verbal self effacement juga ditemukan dalam penelitian ini. Orang Betawi tidak suka menonjolkan diri dan tidak boleh sombong. Gaya verbal self-effacement, di sisi lain, menekankan pentingnya merendahkan diri melalui komunikasi verbal. Penekanan pada rendah hati terobservasi melalui falsafah hidup yang tergambar dalam ungkapan dan peribahasa orang Betawi "aer laut siapa yang ngasinin" yang merupakan nasehat kepada seseorang yang suka memuji atau menyombongkan diri (Chaer, 2009: 4). Ungkapan tersebut merupakan ungkapan tradisional Betawi untuk mengingatkan orang yang suka memuji diri sendiri bahwa sikapnya itu tidak baik dan hendaknya dihentikan. Konteks pemakaian ungkapan tersebut berkaitan dengan interaksi dalam masyarakat. Menurut masyarakat Betawi yang beragama Islam, sikap sombong tidak sesuai dengan ajaran Islam karena menjurus ke sifat takabur yang dibenci Tuhan.

Ungkapan tersebut merupakan ungkapan tradisional Betawi untuk mengingatkan orang yang suka memuji diri sendiri bahwa sikapnya itu tidak baik dan hendaknya dihentikan. Juga jangan sampai terlena oleh pujian orang lain. Konteks pemakaian ungkapan tersebut berkaitan dengan interaksi dalam masyarakat. Menurut masyarakat Betawi yang beragama Islam, sikap sombong tidak sesuai dengan ajaran Islam karena menjurus ke sifat takabur yang dibenci Tuhan.Ungkapan ini berasal dari masyarakat nelayan. Muncul dari kenyataan bahwa memang garamlah yang membuat asin air laut dan bukan benda lain. Tetapi "garam" itu tidak boleh menyombongkan diri karena telah mengasini air laut yang luas. Adapun arti dan maksud pemakaiannya ungkapan ini adalah untuk menasehati, menyindir dan mengingatkan seseorang yang suka memuji diri sendiri, bahwa kebiasaan seperti itu tidak baik dan hendaknya dihentikan. Masyarakat Betawi yang beragama Islam tidak senang kalau ada seorang yang suka memuji diri sendiri. Hal ini sesuai dengan ajaran Islam, karena orang sombong yang akan 
menjurus ke sifat takabur suatu sifat yang dibenci Tuhan. Sebagai seorang manusia tentu ada kelemahannya. Di satu pihak seseorang mungkin hebat, tetapi dalam hal lain ada kelemahannya. Jangan lantas memuji diri bila mengerjakan sesuatu.

Salah satu keterampilan dasar, baik linguistic maupun kultural adalah tahu kapan untuk tidak berbicara dalam komunitas tertentu. Memahami dimana dan kapan harus diam, dan arti dari sikap diam tersebut adalah untuk memperoleh pengetahuan mendalam mengenai struktur dasar dari komunikasi di dunia (Samovar, 336). Dalam kaitannya dengan hal tersebut, Penelitian ini menemukan bahwa Orang Betawi dalam suasana dialog yang tenang, santai penuh canda, berada pada komunikasi konteks rendah, namun seketika dapat berubah pada konteks tinggi dalam situasi dialog yang berpotensi munculnya ketegangan dan menimbulkan perdebatan. Komunikasi konteks tinggi umumnya dipraktikkan jika berinteraksi dengan outgroup-nya, sebaliknya jika berada dalam kelompoknya yang dianggap sudah familiar maka dia cenderung masuk komunikasi konteks rendah.

\section{Multikulturalisme Orang Betawi: Sebuah Warisan Sejarah}

Pluralitas dan heterogenitas masyarakat Indonesia merupakan sebuah keunikan tersendiri bagi bangsa Indonesia yang bersatu dalam suatu kekuatan dan kerukunan beragama, berbangsa dan bernegara. Namun, kemajemukan terkadang membawa berbagai persoalan dan potensi konflik yang berujung pada perpecahan. Hal ini menggambarkan bahwa pada dasarnya, tidak mudah mempersatukan suatu keragaman tanpa didukung oleh kesadaran masyarakat multikultural.

Betawi, sejak dahulunya memang merupakan masyarakat yang terbuka, keterbukaan masyarakat Betawi setidaknya tumbuh dalam sejarah panjang masyarakat Betawi di Jakarta. Mengutip Haesy (2017) setidaknya ada tiga hal yang menyebabkan Betawi tumbuh sebagai masyarakat yang tebuka. Pertama, Betawi sebagai masyarakat terbuka terhadap etnis pendatang, merupakan akar dari proses panjang kehidupan suku Betawi yang selalu bersentuhan dengan kolonialisme. Sejarah panjang proses keberadaan kaum Betawi sebagai ras Melayu (bukan semata-mata etnis), yang hidup di Paparan Sunda (Sunda Land) menurut Ishak (2012) disebabkan oleh cepatnya perkembangan bahasa dan kebudayaan bangsa dari Paparan Sunda ini selama satu sampai 2 millenium. Semua ini menggambarkan, bahwa bangsa Melayu adalah bangsa asli yang berasal dari wilayah kepulauan dalam Paparan Sunda yang salah satu dari rumpunnya kaum Betawi.

Multikulturalisme dan pluralisme orang Betawi yang membentuk karakternya sebagai masyarakat egaliter dengan prinsip ekuitas dan ekualitas (kesetaraan dan keadilan) dengan bangsa dan masyarakat suku bangsa lain. Sebagai masyarakat asli yang terbuka, egaliter dan mampu berinteraksi secara terbuka dengan bangsa dan suku bangsa lainnya, tidak dapat dipungkiri terjadinya proses asimilasi dan akulturasi melalui proses perkawinan dengan bangsa-bangsa lain, seperti Arab, Tiongkok, Eropa, dan Champa. Juga berasimilasi secara domestik dengan warga bangsa serumpun,seperti Sunda, Iawa, Minangkabau, Mandailing, Tapanuli, Banjar, Bugis, Maluku, Bali, Melayu (Lingga), Aceh, Bima, dan lainnya. Proses asimilasi dan akulturasi tersebut memperkuat karakter suatu masyarakat sebagai bagian utama dari masyarakat yang lebih besar, karena di dalam dirinya mengandung nilai kebersatuan (integralitas), nilai keperkasaan, nilai religius, nilai etis, nilai estetis, dan nilai historis (Soetjipto, 1984). Dengan nilai-nilai tersebut, Orang Betawi tumbuh dan berkembang semacam itu menjadi masyarakat yang multikultural dan pluralis (Haesy, 2011: 295).

Kedua, Masyarakat Betawi merupakan kaum yang tidak mempunyai ikatan kedaerahan sebagaimana masyarakat dari berbagai suku bangsa lain. Kaum Betawi bukan kaum migran yang mendiami suatu wilayah dan kemudian mempunyai rencana terhadap daerah asalnya (Haesy, 2017). Orang Betawi adalah sebuah kaum yang menempuh proses sejarah dan dalam proses sejarah itu dia membuka diri karena implusifitasnya dan dia tidak pernah mempertimbangkan asal usul. Hal ini dipertegas oleh pandangan Sejarawan Betawi, 
JJ Rizal (2015) $)^{3}$ yang mengatakan bahwa, Orang Betawi tidak mengenal hari kelahiran. Ketiga, Betawi merupakan masyarakat yang kosmopolit itu siap dengan aneka macam pertemuan, aneka macam yang memungkinkan mereka melahirkan satu kebudayaankebudayaan dan penemuan-penemuan budaya baru yang akhirnya memperkaya dan memperkuat kebudayaan ini.

Keempat, Orang Betawi sebagai bagian dari masyarakat manusia yang dinamis, multikultural dan egaliter, telah menjadi sangat terkondisikan untuk berhadapan dengan realitas masyarakat Jakarta yang majemuk. Penerimaan sosial ini dikarenakan nilai-nilai dan pandangan hidup orang Betawi yang mengedepankan nilainilai religius yang dimilikinya memungkinkan kaum Betawi menjadi peIopor dalam mengharmonisasikan dimensi keislaman dan semangat keindonesiaan dalam mengaktualisasi kesadaran akan kemajemukan. Proses pendidikan kaum Betawi melalui lembaga pendidikan Islam (formal, informal, dan non formal) telah membentuk kesadaran untuk menolak nilai-nilai lama kesukuan (Haesy, 2017: 304). Dalam diri kaum Betawi mengalir esensi nilai kepribadian yang bersumber dari ajaran agama Islam. Kaum Betawi dicirikan oleh kesetaraan (sikap egaliter), agama Islam, bahasa dan kebudayaan. Itulah sebabnya mengapa kaum Betawi tidak memandang penting gelar dan pemeringkatan struktural kehidupan sosialnya. Nilai ini yang memungkinkan kaum Betawi lebih fleksibel dan akomodatif terhadap perubahan sosial

\section{Kesimpulan}

Sebagai suatu ideologi, multikulturalisme dapat menjadi wahana untuk meningkatkan penghargaan atas kesetaraan semua manusia yang melegitimasi keanekaragaman budaya. Namun, kita juga harus menyadari bahwa diantara faktor pemicu konflik dalam multikulturalisme adalah perbedaan agama, sebab agama adalah merupakan sesuatu yang paling asasi dalam diri seseorang dan paling mudah menimbulkan gejolak emosional.

\footnotetext{
${ }^{3}$ Disampaikan pada acara Seri Diskusi Betawi Kita ke-1 tentang "Siapakah Orang Betawi”, Depok, 2015
}

Sejarah mencatat bahwa konflik-konflik yang terjadi di Indonesia pada dasarnya bukanlah disebabkan oleh agama saja, melainkan disebabkan oleh faktor-faktor sosial, ekonomi dan politik, namun agama dijadikan sebagai simbol bahkan sebagai motor penggerak untuk terjadinya konflik antar ummat beragama.

Secara historis, Betawi erat kaitannya dengan konsistensi kultural yang Islami. Akar budaya punya kandungan historis yang khas. Akar budaya Betawi yang Islami sangat kuat memberi warna pada identitas Betawi. Betawi dan Islam seperti dua sisi mata uang. Penelitian ini menemukan, selain lekat dengan nilai-nilai islami, Orang Betawi juga lekat dengan multikulturalisme-nya. Utamanya pada anak muda yang makin kelihatan dimensi multikulturalismenya. Dengan demikian, multikulturalisme Orang Betawi bersumber dari ajaran agama Islam yang kemudian mengejawantah dalam kehidupan sehari-hari sebagai norma budaya dalam kehidupan bermasyarakat.

\section{References}

Azra, Azyumardi. 2006. "Pancasila dan Identitas Nasional Indonesia: Perspektif Multikulturalisme". Dalam Restorasi Pancasila: Mendamaikan Politik Identitas dan Modernitas. Bogor: Brighten Press.

Chaer, Abdul. 2015. Betawi Tempo Doeloe. Jakarta: Masup Jakarta.

Gudykunst.W. 2003. Communicating with Strangers: An Approach to Intercultural Communication (4th ed.). New York: McGraw-Hill.

Haesy, Syamsuddin CH. 2017. Tantangan Esok Kaum Betawi. Dalam buku "Betawi Kita: Doeloe, Kini, dan Esok". Jakarta: Bamus Betawi.

Nakayama, T.K., Martin, J.N. 2007. Intercultural Communicationin Contexts. New York: McGraw-Hill.

Pradipta, Budaya. 2005. Posisi Budaya Betawi dalam Kehidupan Global: Betawi Hebat dan Pentolan dalam Betawi Punye Gaye. Wahyu Wibowo \& Somadi (Ed). Jakarta: PSB UNAS

Saidi, Ridwan. 1997. Profil Orang Betawi. Asal Muasal Kebudayaan dan Adat Istiadatnya. Jakarta: PT. Gunara Karta. 
Samovar, A. Larry., Porter, E. Richard \& McDaniel, R. Edwin. 2010. Communication Between Culture: 7th edition. Boston: Wadsworth.

Shahab, Yasmine. Z. 1997. Betawi Dalam Mite danKenyataan.Dalam Yasmine Zaki Shahab (ed.) Betawi dalam perspektif Kontemporer: Perkembangan, Potensi, dan Tantangannya. Jakarta: Lembaga Kebudayaan Betawi.

Shahab, Yamine. Z. 2004. "Betawi dalam Angka dan Permasalahannya" Makalah Seminar Periodisasi Sejarah Masyarkat Jakarta: Dinas
Kebudayaan dan permuseuman DKI Jakarta.

Suparlan, Parsudi. 2005. Sukubangsa dan Hubungan Antar Sukubangsa. Jakarta: Yayasan Pengembangan Kajian Ilmu Kepolisian.

Ting-Toomey, S. 1999. Communicating Across cultures. New York: The Guilford Press

Ting-Toomey, S. 2005. Identity negotiation theory: Crossing cultural boundaries. In W.B. Gudykunst (Ed.), Theorizing About Intercultural. Thousand Oaks, CA: Sage. 